\title{
Public Health Policy Practice for Early-Age Marriage in Gunung Kidul, Indonesia: An Evaluation of Regent Regulation Practice on Child Health
}

\author{
Restu Anandya Palupi ${ }^{1}$, Wahyu Sulistiadi ${ }^{1,2}$, and Al Asyary ${ }^{2,3 *}$ \\ ${ }^{1}$ Department of Health Administration and Policy, Faculty of Public Health, University of Indonesia, Depok - Indonesia \\ ${ }^{2}$ Center for Educational and Community Services, Faculty of Public Health, University of Indonesia, Depok - Indonesia \\ ${ }^{3}$ Department of Environmental Health, Faculty of Public Health, University of Indonesia, Depok - Indonesia
}

\begin{abstract}
Background: Early-age marriage becomes the raising issue regarding its implication, particularly on child health. The efforts to reduce this issue were by changing, monitor, and evaluate the rule of the limit age of marriage for children which was still inappropriately happened in Indonesia, especially in Gunungkidul. Purpose: This study evaluated the Regent Regulation practice as its both performance and effectiveness in improving child health in this region. Methodology: A qualitative design was used in this evaluation study with an in-depth interview and analyzed all governments' reports as secondary data collecting. Results: Regent Regulation of 36/2015 affected to reduce the case of child marriage in Gunungkidul. It reduced almost a half (45.78\%) of the early-age marriage from 2015 to 2017. Informants confirmed that more than $1 / 3$ divorce cases in this region were decreased as well as the suppressed dispensation for early-age marriage ( $<100$ marriage) and lowest amount of maternity cases on the adolescent group. It was also effective in reducing the low-birth weight, from 2015 to 2017, and stunting cases on children, from 2015 to 2016. Conclusion: Positive externality of Regent Regulation of early-age marriage and its impacts was seen by affecting the spirit of the other regions to follow them.
\end{abstract}

Keywords: early-age marriage; child health; stunting; low birth weight; evaluation; Indonesia.

\section{Introduction}

Child, Early, and Forced Marriage (CEFM) is a term that is internationally known to describe some similar conditions relating to underage marriage [1]. Child-age marriages are known to be a cause for various problems, especially for girls as a much-affected party. In terms of health in general, early marriage is associated with poor reproductive health status such as the high probability of severe anemia and severe Pregnancy Induced Hypertension (PIH) in pregnant women, premature births, unwanted pregnancies, pregnancy terminations (including miscarriage, stillbirth, and abortion), and low birth weight (LBW) [2-4].

Other things that need to be considered, health risks due to early marriage cause a cycle of intergenerational impacts that not only affects the mother but also the child she is born with. In addition to having a higher risk of death at birth, babies of child-aged brides are at a higher risk of dying before 1 year of age, as are LBW risks and malnutrition during their growth period $[5,6]$
The intergenerational growth disorder cycle begins with the birth of LBW babies which will cause growth disruption in their children's period until they generally grow into less severe and short teens. The adolescent is less severe and short if married at an early age it is difficult to avoid early pregnancy which then will lead to the return of the cycle to the birth of babies with low birth weight status $[7,8]$. If these less heavy and short teens get married when they are adults, generally their nutritional status does not change much so that they grow up as less heavy and short adult women who will have the potential to give birth to LBW babies [9]

The marriage age of children in Indonesia is still at $28.02 \%$ - so that placing Indonesia as the country with the second-highest rate of early marriage in ASEAN after Cambodia - requires attention ${ }^{10}$. The government has ratified the age limit for children at 18 years Law No. 1 of 1974 concerning Marriage which regulates the age limit of marriage. In its efforts to mature the age of marriage, the regulation regarding marriage was proposed for judicial review to the Constitutional Court (MK) because it was considered not in accordance with

Corresponding author: al.asyary13@gmail.com 
the times and needed adjustment. However, the failure to bring an effort to mature the marriage age in Law No. 1 of 1974 concerning Marriage to be granted by the Constitutional Court judges did not then dampen the steps of various parties who were concerned about the issue of child marriage. Gunungkidul Regency Special Province of Yogyakarta is one of the regions with a government that has the initiative to take a position on the issue of child marriage. Through the ratification of Gunungkidul Regent Regulation No. 36 of 2015 concerning Prevention of Marriage at the Age of Children, the local government shows its commitment to preventing early marriage. The evaluation of the marriage age limit policy in this study was conducted by photographing the phenomenon that occurred in Gunungkidul Regency, DI Yogyakarta Province through the establishment of a policy by the district government, namely Perbup Gunungkidul No 36/2015 concerning Marriage Prevention at the Age of Children.

\section{Methods}

\subsection{Study design}

This research was carried out by using a qualitative approach to explore and explore the attainment of marriage age regulation in preventing the practice of early marriage through a case study of Gunungkidul Regent Regulation No. 36 of 2015 concerning Prevention of Marriage at the Age of Children. In this study data taken through secondary data sources examined include:

Table 1. Secondary Data Source Documents reviewed in the Analysis of Research Data

\begin{tabular}{|l|l|l|}
\hline No. & Documents reviewed & Source \\
\hline 1 & $\begin{array}{l}\text { Perbup Gunungkidul No } \\
36 / 2015 \text { concerning } \\
\text { Prevention of Marriage at } \\
\text { the Age of Children }\end{array}$ & $\begin{array}{l}\text { Dinas P3AKBPMD } \\
\text { Kab. Gunungkidul }\end{array}$ \\
\hline 2 & $\begin{array}{l}\text { Regent of Gunungkidul } \\
\text { Decree Number 170 / KPTS } \\
\text { / 2016 concerning Draft } \\
\text { Regional Action for } \\
\text { Marriage Prevention for } \\
\text { Children Age 2016-2021 }\end{array}$ & $\begin{array}{l}\text { Dinas P3AKBPMD } \\
\text { Kab. Gunungkidul }\end{array}$ \\
\hline 3 & $\begin{array}{l}\text { The Population Profile } \\
\text { Book of Gunungkidul } \\
\text { Regency }\end{array}$ & $\begin{array}{l}\text { Dinas P3AKBPMD } \\
\text { Kab. Gunungkidul }\end{array}$ \\
\hline 4 & $\begin{array}{l}\text { Head Presentation of } \\
\text { DP3AKBPMD on Thematic } \\
\text { Discussion on Preparation } \\
\text { of Profile of Fulfillment of } \\
\text { DIY Child Rights on May } \\
\text { 16, 2018 }\end{array}$ & $\begin{array}{l}\text { Dinas P3AKBPMD } \\
\text { Kab. Gunungkidul }\end{array}$ \\
\hline 5 & $\begin{array}{l}\text { MoU on Prevention of } \\
\text { Early Marriage in }\end{array}$ & $\begin{array}{l}\text { Dinas P3AKBPMD } \\
\text { Kab. Gunungkidul }\end{array}$ \\
\hline
\end{tabular}

\begin{tabular}{|c|c|c|}
\hline No. & Documents reviewed & Source \\
\hline & $\begin{array}{l}\text { Gedangsari District and } \\
\text { Panggang District District. } \\
\text { Gunungkidul }\end{array}$ & \\
\hline 6 & $\begin{array}{l}\text { The decision of District } \\
\text { Head of Playen, Sub- } \\
\text { District Head of Ngawen, } \\
\text { Sub-District Head of } \\
\text { Girisubo, Sub-District Head } \\
\text { of Purwosari, Camat Semin, } \\
\text { Sub-District Head of } \\
\text { Karangmojo, and Sub- } \\
\text { District Head of Wonosari } \\
\text { about Changing Decision on } \\
\text { Establishing Victims of } \\
\text { Violence Against Women } \\
\text { and Children Forum } \\
\text { (FPK2TPA) }\end{array}$ & $\begin{array}{l}\text { Dinas P3AKBPMD } \\
\text { Kab. Gunungkidul }\end{array}$ \\
\hline 7 & $\begin{array}{l}\text { Data on Case Reports } \\
\text { Received by Type in the } \\
\text { Wonosari Religious Court } \\
\text { in } 2011-2017\end{array}$ & $\begin{array}{l}\text { Wonosari Religious } \\
\text { Court }\end{array}$ \\
\hline 8 & $\begin{array}{l}\text { Data on Report of Cases } \\
\text { Sentenced by Type in the } \\
\text { Wonosari Religious Court } \\
\text { in } 2011-2017\end{array}$ & $\begin{array}{l}\text { Wonosari Religious } \\
\text { Court }\end{array}$ \\
\hline 9 & $\begin{array}{l}\text { Data on Number of } \\
\text { Marriage, Divorce, Divorce, } \\
\text { and Referral (NTCR) } \\
\text { Closed for } 2012-2017\end{array}$ & $\begin{array}{l}\text { Ministry of } \\
\text { Religion Kab. } \\
\text { Gunungkidul }\end{array}$ \\
\hline 10 & $\begin{array}{l}\text { Data on Work Program } \\
\text { Decreasing Early Marriage } \\
\text { by the Ministry of Religion, } \\
\text { Kab. Gunungkidul }\end{array}$ & $\begin{array}{l}\text { Ministry of } \\
\text { Religion Kab. } \\
\text { Gunungkidul }\end{array}$ \\
\hline 11 & $\begin{array}{l}\text { The Book of Patterns for the } \\
\text { Development of Sakinah } \\
\text { Families and Villages } \\
\text { Assisted by the Sakinah } \\
\text { Family (DBKS) by the } \\
\text { Field of Islamic Affairs of } \\
\text { the Regional Office of the } \\
\text { Ministry of Religion of DIY }\end{array}$ & $\begin{array}{l}\text { Ministry of } \\
\text { Religion Kab. } \\
\text { Gunungkidul }\end{array}$ \\
\hline 12 & $\begin{array}{l}\text { Sakinah Family Foundation } \\
\text { Book: Independent Reading } \\
\text { of Bride Candidates by Sub- } \\
\text { Directorate of Sakinah } \\
\text { Family Development } \\
\text { Directorate General of } \\
\text { Islamic Bimas Ministry of } \\
\text { Religion of the Republic of } \\
\text { Indonesia } 2017\end{array}$ & $\begin{array}{l}\text { Ministry of } \\
\text { Religion Kab. } \\
\text { Gunungkidul }\end{array}$ \\
\hline 13 & $\begin{array}{l}\text { Marriage and Divorce Data } \\
\text { for } 2012-2017\end{array}$ & $\begin{array}{l}\text { Department of } \\
\text { Population and } \\
\text { Civil Registration } \\
\text { District. } \\
\text { Gunungkidul }\end{array}$ \\
\hline 14 & DPA Data Dinas Dikpora & Department of \\
\hline
\end{tabular}




\begin{tabular}{|c|c|c|}
\hline No. & Documents reviewed & Source \\
\hline & $\begin{array}{l}\text { Kab. Gunungkidul The } \\
2018 \text { Middle School Basic } \\
\text { Education Program } \\
\text { Enhances Students and } \\
\text { Education Personnel } \\
\text { Activities on Gender } \\
\text { Workshop }\end{array}$ & $\begin{array}{l}\text { Education, Youth } \\
\text { and Sports Kab. } \\
\text { Gunungkidul }\end{array}$ \\
\hline 15 & $\begin{array}{l}\text { Design of Gunungkidul } \\
\text { Regency RPJMD for 2010- } \\
2015 \text { and 2016-2021 }\end{array}$ & Official website \\
\hline 16 & $\begin{array}{l}\text { Trends in Stunting Events } \\
\text { in Gunungkidul Regency in } \\
2012-2016\end{array}$ & $\begin{array}{l}\text { District Health } \\
\text { Office } \\
\text { Gunungkidul } \\
\end{array}$ \\
\hline 17 & $\begin{array}{l}\text { Data on Youth Delivery in } \\
\text { Gunungkidul District 2014- } \\
2017\end{array}$ & $\begin{array}{l}\text { District Health } \\
\text { Office } \\
\text { Gunungkidul } \\
\end{array}$ \\
\hline 18 & $\begin{array}{l}\text { LBW incidence data in } \\
\text { Gunungkidul Regency in } \\
\text { 2011-2017 }\end{array}$ & $\begin{array}{l}\text { District Health } \\
\text { Office } \\
\text { Gunungkidul } \\
\end{array}$ \\
\hline 19 & $\begin{array}{l}\text { Presentation of Former } \\
\text { Head of KUA in } \\
\text { Gedangsari District on the } \\
\text { Prevention of Age of } \\
\text { Children in Gedangsari } \\
\text { Sub-District }\end{array}$ & $\begin{array}{l}\text { Former Head of } \\
\text { KUA, Gedangsari } \\
\text { District }\end{array}$ \\
\hline 20 & $\begin{array}{l}\text { Books Sharing Space } \\
\text { Sharing Burden: Reflections } \\
\text { on the Program to Eliminate } \\
\text { Violence Against Women in } \\
\text { the Community }\end{array}$ & $\begin{array}{l}\text { Rifka Annisa } \\
\text { Yogyakarta } \\
\text { Woman Crisis } \\
\text { Center }\end{array}$ \\
\hline 21 & $\begin{array}{l}\text { MoU Prevention of Early } \\
\text { Marriage Purwosari } \\
\text { District, Kab. Gunungkidul }\end{array}$ & $\begin{array}{l}\text { Rifka Annisa } \\
\text { Yogyakarta } \\
\text { Woman Crisis } \\
\text { Center }\end{array}$ \\
\hline
\end{tabular}

\subsection{Study setting}

The study was conducted in Gunungkidul Regency, DI Yogyakarta to evaluate the achievement of marriage age limit settings through a case study of Gunungkidul Regent Regulation No. 36 of 2015 concerning Prevention of Marriage at the Age of Children in April-June 2018.

\subsection{Ethics}

The ethical feasibility of research on research and procedures carried out by researchers in the field is carried out as a condition before data collection is carried out in the field. The study was conducted after obtaining a recommendation from the Ethics Study Team of the Faculty of Public Health of the University of Indonesia with the Decent letter number Ethic 387/UN2.F10/PPM.00.02/2018 and through licensing procedures to retrieve research data.

\section{Results}

Policy evaluation studies are carried out on this policy because it is considered appropriate because there has been a change in the decline in early marriage and marriage dispensation requests as well as community perspectives since the PPUA Regulation was enacted and implemented in 2015. Changes in underage marriage trends are shown in the data presented in subchapter on policy performance, while changes in the perspective of the community can be seen from the results of interviews with informants who stated that people began to think more difficult at this time if they want to marry off children at an age that is too young or underage. So that the study evaluation policy is suitable because of changes that seem almost comprehensive since the emergence of Perbup.

" Heu" euh, until now if there are good indicators, in Saptosari, the real indicators in the community are quite good. "Wah saiki nikahne boy iki angel " (now marrying this child is difficult). It was from the old preachers, such voices had appeared, this was a very good indicator, meaning they already had awareness even though at first it was rather "depressed". "—Wijang Eka Aswarna, Secretary of the Gunungkidul District Social Service.

\subsection{Performance of Regent Regulation Practice}

The performance of Gunungkidul Perbup policy No. 36 of 2015 concerning Marriage Prevention on the Age of Children can be seen through the achievement of several indicators. Indicators that show the progress of achieving this child-age marriage prevention effort can be seen from several things such as:

a) The number of marriages of children age recorded at the Ministry of Religion,

b) Dispensation requests submitted to the Religious Courts, and

c) Birth of teenagers recorded by the Health Office.

The complexity of the phenomenon of child age marriage makes judging the performance of its policies cannot be seen through just one perspective. Data on underage marriages can show the incidence of child marriage that is legal and recorded in the KUA and reported to the Ministry of Religion Office, while the marriage dispensation request data shows the number of underage brides who intend to legalize their marriage so they must register a marriage dispensation request and be tried at Religious courts. In addition, some marriages may not be recorded due to the occurrence of extramarital pregnancies, so that detection can be done through the screening of labor data by mothers who are teenagers and recorded in data on adolescent delivery. The following are indicator data commonly used to assess the success of child age marriage prevention efforts obtained by researchers from the field and their descriptions: 
Table 2. Number of Marriage Underage in Gunungkidul Regency in 2012-2017

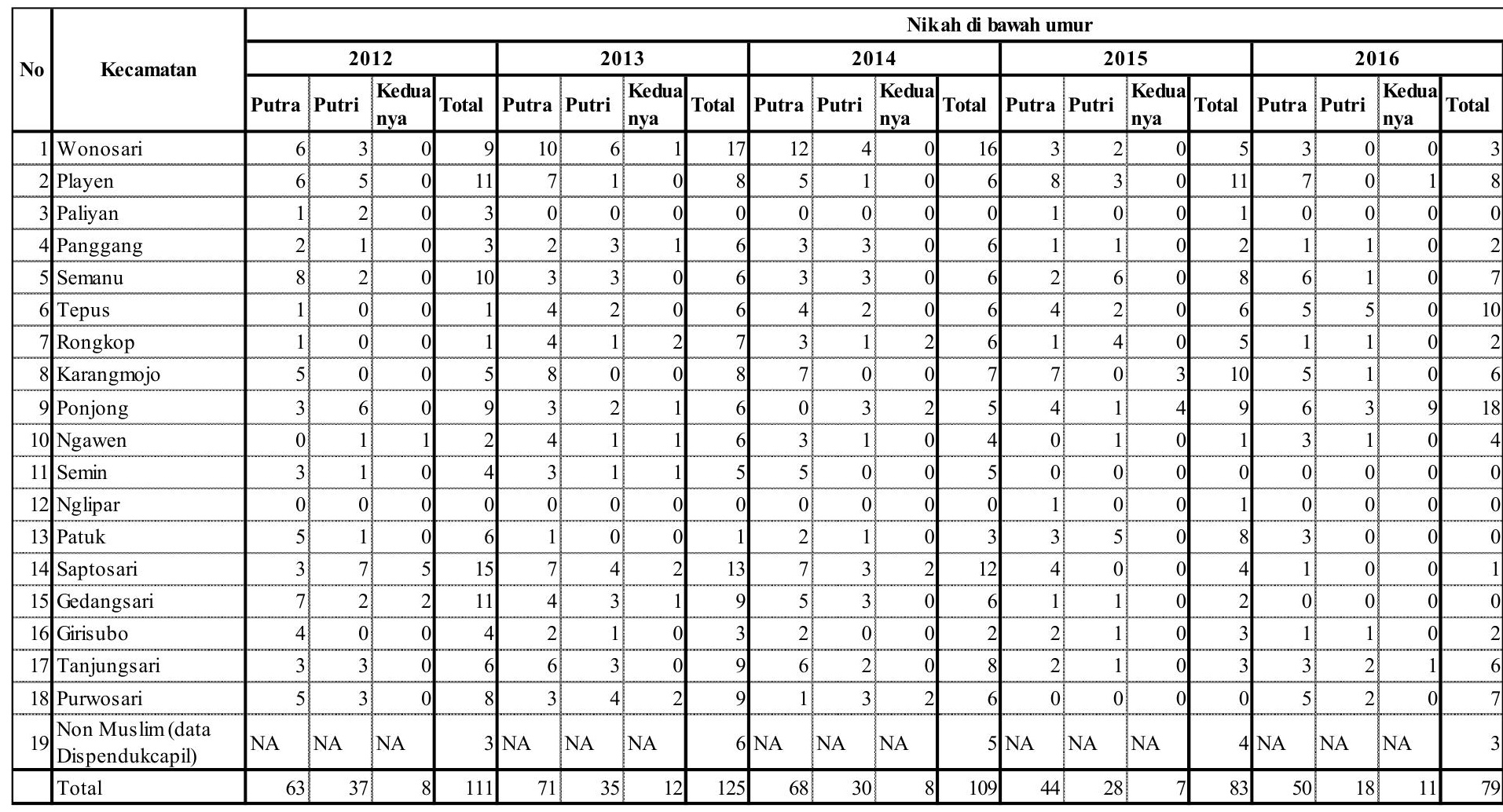

Source: NTCR data Ministry of Religion and underage marriage data Dispendukcapil Gunungkidul Regency (rep 
Data on underage marriage recorded both in the Ministry of Religion and in the Department of Population and Civil Registration of Gunungkidul Regency showed an increase in 2012 and 2013. In 2014 the figure has begun to decline presumably because of the emergence of efforts at the sub-district level as mentioned in history the formation of the Perbup in the previous sub-chapter. Pilot efforts in several sub-districts which are indeed enclaves of marital problems at the age of the child made the decline that occurred quite significant. Post-Perbup is formed so that it can be seen that the decline that occurs is increasingly showing a positive trend. The numbers even dropped so much that less than half the number of underage marriages in 2012.

In addition to this, there is a phenomenon that deserves further study in further research on marriage data based on gender. In the data, it appears that underage marriage is mostly done by men rather than women. Based on Law No. 1/1974 concerning Marriage, indeed the marriage dispensation applied to men is if male patients are less than 19 years old. Higher age requirements for men are believed to be due to the heavier responsibilities that must be carried out by men who will act as head of the family. More mature age is expected by men to be better prepared and better able to be responsible for their families. The obligation to provide for the family carried by men is one factor, with a more mature age men are expected to be more capable.

This is related to the number of reasons for divorce in 2016 which were recorded by the Gunungkidul Regency Dispendukcapil which occurred mostly due to economic problems. If a man does not have the ability to meet his family's financial needs, the resilience of a family will become weak and prone to divorce. Divorce cases in Gunungkidul Regency have experienced a downward trend from 2013 until the birth of the PPUA Regulation in 2015. Although it cannot be stated definitively that this is a contribution from the PPUA Regulation, this is seen as a positive thing by various parties.

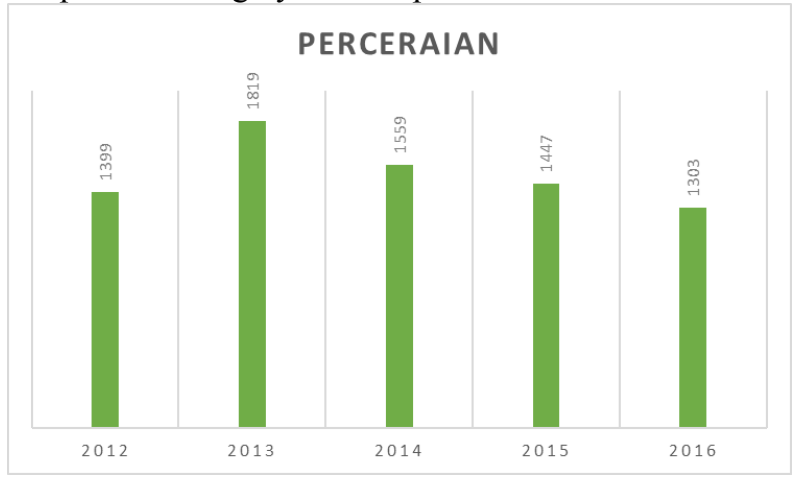

Fig. 1. Cases of Divorce in Gunungkidul Regency in 20122016

Based on the information from the Religious Court Judge interviewed by the researcher, it was found that there was a downward trend in the divorce case he handled which was a divorce because the couple was a couple who married underage. Data on recording divorce cases based on age was not obtained by researchers. Only data from Dispendukcapil found that in 2016 the divorce cases that occurred in Gunungkidul Regency were from the wife's lawsuit, namely 24 cases of divorce claims, while the lawsuit by the husband was only 7 cases. This can certainly be of particular concern.

"Decreasing as well, there have been only 1 to 3 years in the past. I happen to be the chairman of the assembly. That's because her husband said, 'I don't want to live in my mother's house.' $S$ aya says, ' $M$ as.. ', Divorce is a coincidence that I handled the divorce. Why is this said to be marriage dispensation, is n't it the age when now, for example, if he keeps divorcing in 2015, for that guy, there hasn't been 19 years. 'Mas, why did you file a marriage permit?' 'Yes ma'am, why mother ta $h u$ ?' 'Yes, ta h u wrote.'

(Case example) Divorce originating from a dispensation, $B u$, not from an ordinary divorce if it is that much, it just goes up and down. "-Endang Sri Hartati, Judge of the Wonosari Religious Court

But as mentioned before, observing the phenomenon of child marriage cannot only be seen from one perspective. Data on marriage dispensation requests are also indicators that can reveal a picture of the phenomenon that occurs.

Table 3. Number of Requests for Dispensation of Marriage by Gunungkidul District Men and Women in 2012-2017

\begin{tabular}{|c|c|c|c|c|c|c|c|}
\hline \multirow{2}{*}{$\begin{array}{c}\text { No } \\
\cdot\end{array}$} & \multirow{2}{*}{$\begin{array}{c}\text { sub- } \\
\text { district }\end{array}$} & \multicolumn{6}{|c|}{$\begin{array}{l}\text { Request for dispensation to } \\
\text { married* }\end{array}$} \\
\hline & & $\begin{array}{r}201 \\
2\end{array}$ & $\begin{array}{r}201 \\
3\end{array}$ & $\begin{array}{r}201 \\
4\end{array}$ & $\begin{array}{r}201 \\
5\end{array}$ & $\begin{array}{r}201 \\
6\end{array}$ & $\begin{array}{r}201 \\
7\end{array}$ \\
\hline 1 & Wonosari & 15 & 10 & 10 & 7 & 8 & 6 \\
\hline 2 & Playen & 10 & 10 & 9 & 12 & 4 & 3 \\
\hline 3 & Paliyan & 5 & 7 & 4 & 4 & 3 & 4 \\
\hline 4 & Grilled & 8 & 10 & 9 & 6 & 3 & 2 \\
\hline 5 & All right & 10 & 8 & 15 & 11 & 7 & 5 \\
\hline 6 & Tepus & 14 & 14 & 8 & 10 & 9 & 4 \\
\hline 7 & Rongkop & 5 & 6 & 6 & 6 & 1 & 1 \\
\hline 8 & $\begin{array}{l}\text { Karangm } \\
\text { ojo }\end{array}$ & 8 & 7 & 14 & 11 & 4 & 7 \\
\hline 9 & Ponjong & 14 & 12 & 14 & 9 & 11 & 9 \\
\hline 10 & Ngawen & 4 & 5 & 4 & 2 & 2 & 4 \\
\hline 11 & Semin & 6 & 6 & 5 & 1 & 3 & - \\
\hline 12 & Nglipar & 6 & 6 & 9 & 9 & 2 & 2 \\
\hline 13 & Patuk & 13 & 12 & 6 & 5 & 2 & 3 \\
\hline 14 & Saptosari & 16 & 14 & 16 & 7 & 1 & 6 \\
\hline 15 & $\begin{array}{l}\text { Gedangsa } \\
\text { ri }\end{array}$ & 5 & 6 & 9 & 2 & 3 & 1 \\
\hline
\end{tabular}




\begin{tabular}{|c|c|c|c|c|c|c|c|}
\hline \multirow[t]{3}{*}{ No } & \multirow{3}{*}{$\begin{array}{l}\text { sub- } \\
\text { district }\end{array}$} & \multicolumn{6}{|c|}{$\begin{array}{l}\text { Request for dispensation to } \\
\text { married* }\end{array}$} \\
\hline & & 201 & 201 & 201 & 201 & 201 & 201 \\
\hline & & 2 & 3 & 4 & 5 & 6 & 7 \\
\hline 16 & Girisubo & 12 & 14 & 2 & 8 & 1 & 3 \\
\hline 17 & $\begin{array}{l}\text { Tanjungsa } \\
\text { ri }\end{array}$ & 9 & 9 & 8 & 3 & 10 & 1 \\
\hline 18 & Purwosari & 12 & 10 & 5 & - & 5 & 2 \\
\hline \multirow[t]{2}{*}{19} & $\begin{array}{l}\text { Non } \\
\text { Muslim }\end{array}$ & NA & NA & NA & NA & NA & NA \\
\hline & Total & 172 & 166 & 153 & 113 & 79 & 63 \\
\hline
\end{tabular}

Source: data from the Wonosari Religious Court (reprocessed)

*) available data is only Moslem, age provisions propose 16-year dispensation for women and 19 years for men

Marriage dispensation is an application that must be submitted by a couple who wants to get married but has several obstacles, namely: (1) constraints on administrative registration time, and (2) constraints on the lack of age of the applicant to marry based on the provisions of Law No. 1 of 1974 concerning Marriage. The time constraints on administrative registration occur generally because the registrant wants to immediately get married while based on administrative provisions generally there must be a gap of 10 days after the registration is declared accepted by the KUA. This is done so that there is time for an announcement in KUA of candidates to be married in an effort to avoid conflict if it turns out that there are fake data such as falsifying the status of one of the prospective bride who claimed to be single even though he was married. If the applicant or prospective bride wants to hold a marriage with a faster time then it must file a dispensation. The second condition that requires Catin to submit dispensation is the problem of the lack of age of prospective bride according to the age standard stipulated in the Marriage Law, namely 16 years for women and 19 years for men.

The lack of age of the prospective bride who causes having to submit a marriage dispensation request is carried out while collecting the administrative requirements needed to register the marriage with the KUA. Afterward, if it is found that the age of the prospective bride is less than the provisions, the KUA will issue form $\mathrm{N} 7$ and $\mathrm{N} 8$ as a refusal which then prospective bride must register the marriage dispensation request to the Religious Court. the prospective bride had to attend a hearing at the Religious Court before finally getting a verdict from the judge whether or not the request was granted. If their request is granted by the judge, they can return to the KUA to be legally married.

The marriage dispensation data in table 3 does show a number different from the marriage number in the previous table, which is table 2 . This does not necessarily imply that the existing data is not synchronous between agencies, but the application data for marriage dispensation does not necessarily represent the occurrence of the official marriage. It could be that the applicant is dispensing especially if it is his male party, so the marriage is outside the Gunungkidul Regency so that the marriage registration does not occur in Gunungkidul Regency but in the area of his bride even though the request for marriage dispensation is recorded in Gunungkidul Regency. In addition to this, there is also the possibility of a request that has been granted by the judge but is canceled by the bride and groom. There is also the possibility of a dispensation being submitted at the end of the year so that the marriage registration takes place the following year.

" Wslm. Iyah, among other things, does not have to be married in GK, it can be in other areas, especially those who are less of a husband's clone. Or it has also been given dispensation but not used. Or the expression of the end of the next year. "-Yosep Muniri, Former Head of KUA, Gedangsari District (via WhatsApp)

From Table 3 above, it can be seen that the marriage dispensation request has a positive trend with the decline that occurred especially after 2015 which was the year the Perbup was ratified. However, if observed the decline began to occur in the previous year, namely since 2013, in which efforts to prevent child age marriages have actually been initiated at the sub-district level. Many factors that may have an impact, but in 2015 since it was passed declaring, the application for a dispensation to marry increasingly decreased quite significantly to the number of cases under 100 .

In addition to this, the phenomenon of child age marriage can also be observed from the number of recorded teen births. This is because not all child-age marriages are officially recorded at the KUA or in the Ministry of Religion's data, sometimes there are underthe-hand marriages or illegal (sirri) marriage or cases of pregnancy out of wedlock that is not later married because of a change in the mindset of the woman herself immediately want to get married because they think that it is not always a way out.

" There is no (report of forced marriage to children), because what happens here is yes, because of the social effects, so what is it, get pregnant first. Well like that, then if possible what happens in the community is when they are pregnant, then how do they try the man responsible and so on, right, now for this time, it means often as time goes by we return to women who are victims or say children so that is still under 18 years old, how is that, does it really want to be married or married to the man, or how, until today, there are some who later decide, do not want to, because it does not mean they do not want a marriage to the child, yes, does it also still cannot be legalized, huh, when the child is born there is a notion and so is not biased like that. And they think that if I get married, or married by a man, not necessarily my life will be better. In fact, it will worsen and I will get 
worse because I already know how it is, how the man behaves, I have fallen into the times I want to plunge myself, now that there is already a mindset that there are some victims, well, and, yes ... we just support it, not later, and the family finally can, can accept, and increased support, family support, social support is also good. "-Arum Rohayati, P2TP2A Psychological Counselor

For this reason, the data on childbirth can also represent the phenomenon of child marriage. From the data obtained from sources from the Health Office, data on adolescent deliveries have decreased from year to year since the ratification of the Marriage Prevention Regulation for the Age of Children.

Table 4. Number of Gunungkidul District Youth Deliveries for 2014-2017

\begin{tabular}{|c|c|c|c|c|c|c|}
\hline \multirow[t]{2}{*}{ No. } & \multirow{2}{*}{$\begin{array}{c}\text { Age } \\
\text { Group } \\
\text { (years) }\end{array}$} & \multicolumn{4}{|c|}{ Year } & \multirow[t]{2}{*}{ Total } \\
\hline & & 2014 & 2015 & 2016 & 2017 & \\
\hline 1 & $10-14$ & 8 & 1 & 1 & 4 & 14 \\
\hline 2 & $15-17$ & 94 & 123 & 105 & 88 & 410 \\
\hline 3 & 18 & 270 & 281 & 204 & 165 & 920 \\
\hline \multicolumn{2}{|c|}{ Total } & 372 & 405 & 310 & 257 & \\
\hline
\end{tabular}

Source: data from Gunungkidul District Health Office (reprocessed)

Based on the existing indicators, it was found that the decline in child age marriage had begun to be seen from 2 years before the PPUA Regulation was ratified and enacted, this was suspected to be a contribution from efforts that had emerged in the sub-district. After the PPUA Regulation was ratified and put into effect in 2015, the decline was seen in several indicators increasingly showed a significant decline so that it can be said that the PPUA Regulation contributed to the role of PPUA efforts carried out in Gunungkidul District.

\subsection{The effectiveness of Regent Regulation Practice}

The effectiveness is seen from the comparison of the results of the efforts to prevent child age marriages with their goals based on the mandate contained in the Gunungkidul Regulation No. 36 of 2015 concerning Prevention of Marriage at the Age of Children (PPUA). Gunungkidul Regent Regulation No. 36 of 2015 concerning PPUA stipulated on July 24, 2015, has the following objectives:

1) guarantee the protection of children and the fulfillment of their rights so that children can live, grow and participate according to their dignity and dignity optimally,

2) make children as qualified human resources, have a noble character, and can live well,

3) minimize the occurrence of violence against children,
4) prevent domestic violence (domestic violence),

5) improve maternal and child health status in Gunungkidul Regency,

6) minimize the occurrence of dropouts, and

7) reduce poverty in the region.

The mandate was based on the fact that before the establishment of the Perbup, child marriages in Gunungkidul Regency were recorded to be quite high each year so that it was deemed to require a legal umbrella and carried out more institutionalized prevention efforts involving cross DPOs and agencies within the Gunungkidul Regency government.

The objectives contained in the PPUA Regulation are actually complex indicators, require in-depth study, and measurement is long-term. Indicators of increasing $\mathrm{MCH}$ status, for example, are contributions from many factors that cannot be assessed only from one side. In relation to PPUA, a number of indicators related to maternal and child health which can be collected include the trend of cases of unwanted pregnancies (UP) which decreased from data in 2015 which showed 236 cases of UP to as many as 121 cases of UP in 2016. UP is generally experienced by teenagers who do not want the pregnancy. However, the downward trend in UP cases from 2015 to 2016 provides a positive picture, seeing that 2015 was the first year of the implementation of the PPUA Regulation.

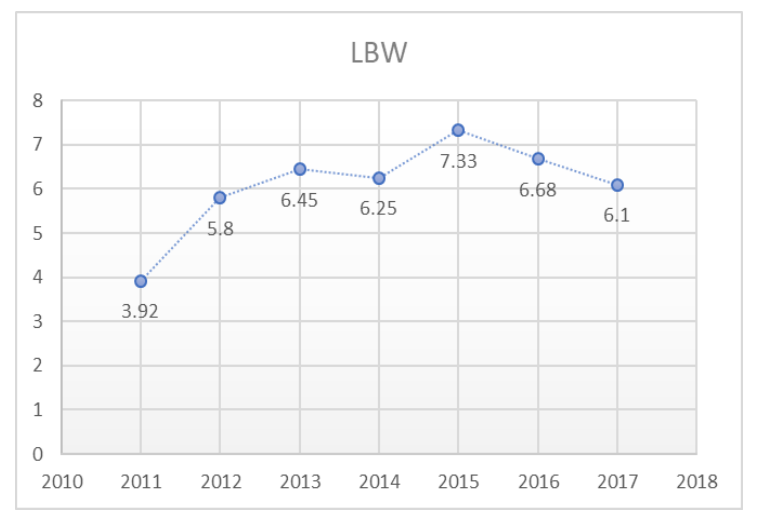

Fig. 2. The trend of LBW cases in Gunungkidul Regency Source: data from the Gunungkidul District Health Office 2018 (reprocessed)

Also based on the theory of early marriage link then the marriage age of children at risk for having a baby with status Infant Low Birth Weight (LBW) as one of the causes of maternal mortality and infant mortality. This happens because generally the nutritional status and readiness of the sexual organs of adolescent mothers are not ready for conception or pregnancy, so they usually affect the weight of children born. The trend of LBW cases based on data compiled by the Gunungkidul District Health Office also decreased after 2015 since the enactment of the Regulation. It is suspected that this is a contribution froPPUA's effort to contribute to the 
reduction in the number of mothers of adolescents who are at high risk for giving birth to babies with LBW status because of the efforts of the relevant agencies to assist these at-risk mothers. Even though there were fluctuations throughout 2011 to 2017 , but due to the limited data and research, there were no factors that could cause fluctuations throughout the year.

"... For child mortality, the trend has decreased quite well. Not only that, BBL, low birth weight, it also decreased because of the teen mother ju $g$ is not there, is minimized. Then if teenagers get pregnant also the quality is better, not with anemic conditions, it has all improved. So not only one indicator. And the teenage reproductive health is also good because of the continued HIV rate of STIs, then we also have the PKPR (Youth Care Health Service) service where there are data on disorders of reproductive health in teenagers who visit, teenagers with smoking disorders, alcohol, they are all there. We see from evaluating those achievements. "Dr. Trianawati, Head of Community Health \& Nutrition Section, Gunungkidul District Health Office

The stunting data that was collected was as follows:

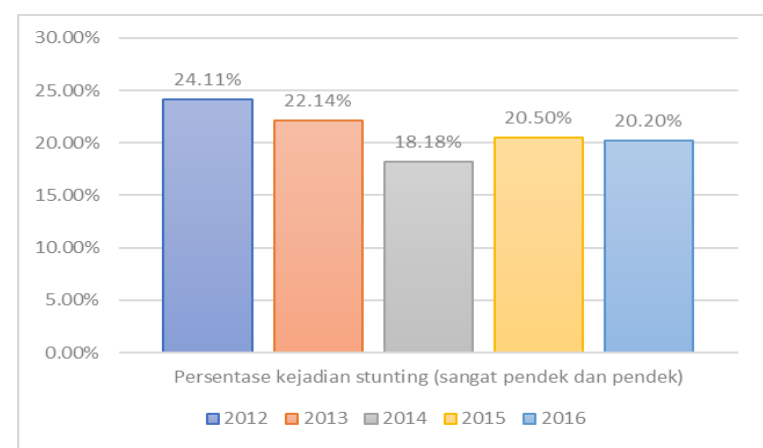

Fig. 3. Percentage of Stunting Events in Gunungkidul Regency Source: Gunungkidul District Health Office

\section{Discussions}

Preventing violence against women and children by preventing marriage at the age of the child is one of the ways that can be taken. From the data obtained, there is a trend that the cases of violence received by the relevant agencies show a good decline. Although cases of violence against children had risen in 2016 but continued to show a decline in the following year. More in-depth data analysis and a qualitative approach to analyzing cases of violence that occur are indeed needed to strengthen the analysis whether indeed the decline is a contribution to the reduction of child marriages, but this becomes a separate limitation in this study.

If the phenomenon is proven then this is in line with research that states that child marriage is indeed related to the occurrence of violence in the form of sexual violence, physical violence, or psychological violence [11-13]. In the footnote of the data provided by DP3AKBPMD, it is stated that cases of child abuse are dominated by types of cases of sexual violence. Early marriage does increase the risk of physical violence by $34 \%$ and $21 \%$ for sexual violence ${ }^{13}$. There $32 \%$ of women married under the age of 15 experienced first forced sex [11].

Child marriage is clearly known to have an impact on the health status of a woman as a mother and for the child, she is born with. Some health impacts for women who have been studied and are related to underage marriage are complications of pregnancy, unwanted pregnancy, SEZ and anemia [3]. Some of the complications of pregnancy are because statistically young married women usually have poor reproductive health status [3]. This is in line with the statement from the Head of the Family Health \& Community Nutrition Section, Gunungkidul District Health Office stating that after many screening after the implementation of the policy, many netted teenagers with anemia status or poor nutritional status.

Based on the data delivered, it can be seen that along with the decline in child marriage cases after the implementation of the PPUA Regulation, the number of unwanted pregnancies has decreased. Improving the quality of maternal and child health can also be observed from the decline in LBW cases that decrease every year after the PPUA policy is implemented. This is very possible because the better access of the community to health services is due to the obligation of the clinician to access pre-marital health services which at the same time provide space for health workers to detect high-risk groups and provide the assistance they need. In the theory of Early Marriage Link, LeFevre (2001) illustrates that early marriage contributes to the increased risk of maternal death and illness as well as the risk of infant mortality and illness, which even if a baby girl can survive the same cycle will repeat and continue to the next generation [14].

Child marriage is also suspected to cause anthropometric failure or anthropometric failure such as stunting, wasting, and underweight because women who marry young are more likely to have poor reproductive health status $[3,15]$. This study found that there was a tendency to decrease the incidence of stunting in Gunungkidul Regency after the enactment of the PPUA Regulation. It can be seen that even since 2013 there has been a decline until in 2014 the decline showed more positive results. Increasing access to pre-marital health services by prospective brides to the Puskesmas as an administrative requirement for registering marriages is one factor. However, this policy in 2013 was only carried out in Gedangsari Sub-District as a PPUA pioneer. In 2015, unfortunately, there was an increase even though in 2016 there was a decline again. Data limitations and limitations of the study are the causes so that it cannot be done a more in-depth study of this phenomenon on the stunting indicator related to the decline in cases of child marriage. 


\section{Conclusion}

In general, Regent Regulation No. 36/2015 concerning Marriage Prevention at the Age of Children gives a performance in decreasing the incidence of child marriage in Gunungkidul Regency. The effectiveness of this policy practice reflected since 2012 and believed to be a contribution from efforts that have emerged in the sub-district, after the PPUA Regulation was enacted and enacted in 2015 the achievement of several indicators such as the number of underage marriages, the number of marriage dispensation requests, and the number of teen births shows a significant decrease. The PPUA regulation is a package with the success that seems to have a positive externality by spreading enthusiasm for other regions to imitate the steps they take.

\section{Acknowledgment}

This study was supported by Directorate for Research and Community Services, University of Indonesia (DRPM-UI). We thank to several parties which consisted of: University of Indonesia (UI), and The Gunungkidul District Local Government.

\section{Conflict of Interest}

The authors declare no potential conflict of interests.

\section{References}

1. WHO, Child, early and forced marriage legislation in 37 Asia-Pacific countries. Geneva, World Health Organization, (2016)

2. D. Godha, D.R. Hotchkiss, A.J. Gage, Association between Child Marriage and Reproductive Health Outcomes and Service Utilization: A Multi-Country Study from South Asia, J. Adolesc Heal. 52(5), 552-558 (2013)

3. R. Prakash, A. Singh, P.K. Pathak, S. Parasuraman, Early Marriage, Poor Reproductive Health Status of Mother And Child Well-Being in India. BMJ Sex. Reprod. Heal. (2011)

4. M. Shah, S. Prajapati, V. Sheneeshkumar, Adolescent Pregnancy: Problems and
Consequences, Apollo Med. 9(3), 176-180 (20120

5. UNICEF, BPS, Pending Progress: Analysis of Data on Childhood Marriage in Indonesia, Jakarta (2015)

6. V. Salvi, Child Marriage in India: A Tradition with Alarming Implications, Lancet 373(9678), 18261827 (2009)

7. I. Unluoglu, E. Saatci, E. Akpinar, Women Family Physicians: A Career in Academic Family Medicine - An Example from Turkey, Fam. Med. \&amp. Prim. Care. Rev. 17(1), 48-53 (2016)

8. H.Y. Yong, M.S. Zalilah, C.W. Tan, S.J. Koo, PrePregnancy BMI and Intake of Energy And Calcium are Associated with the Vitamin D Intake of Pregnant Malaysian Women, Fam. Med. \&amp; Prim. Care. Rev. 19(4), 417-423 (2017)

9. Coordinating Ministry for People's Welfare, Policy Framework for the National Movement for the Acceleration of Nutrition Improvement in the Framework of the First Thousand Days of Life (1000 HPK Movements), Jakarta (2013)

10. BPS, 2016 People's Welfare Indicator, Jakarta (2017)

11. A. Erulkar, Early Marriage, Marital Relations and Intimate Partner Violence in Ethiopia, Int. Perspect Sex Reprod. Health., 6-13 (2013)

12. M. Nasrullah, R. Zakar, M.Z. Zakar, Child Marriage and Its Associations with Controlling Behaviors and Spousal Violence Against Adolescent and Young Women in Pakistan, J. Adolesc. Heal. 55(6), 804-809 (2014)

13. S. Pandey, Physical or Sexual Violence Against Women of Childbearing Age Within Marriage in Nepal: Prevalence, Causes, and Prevention Strategies, Int. Soc. Work. 59(6), 803-820 (2016)

14. J.L. Fevre, R. Quiroga, E. Murphy, Future Options Foreclosed: Girls Who Marry Early, Early Marriage and Child Spouses (2004)

15. A. Talukder, R.S. Rahman, Z. Hossain, Factors Affecting Stunting among Under-Five Children In Bangladesh, Fam. Med. \&amp; Prim Care Rev. 20(4), 356-362 (2018) 